\title{
Isolation and Characterization of Fenitrothion (Organophosphate Insecticide) Degrading Fungi from Paddy Fields
}

\author{
T. Sudha Rani and P. Suvarnalatha Devi* \\ Department of Applied Microbiology, Sri Padmavati Mahila Visvavidyalayam, Tirupati - 517 502, A.P, India.
}

\begin{abstract}
Fenitrothion - Organophosphate insecticide is a cheap and widely used Insecticide throughout worldwide since 1959 and play an important role in modern farming and food production. It is commonly used in Paddy, Cotton, Fruits and Vegetables for controlling beetles, borers, fruit flies, foliar-feeding larvae, nematodes. Fenitrothion is dangerous to all living ecosystem, Excessive exposure to Fenitrothion effect the brain and peripheral nervous system of humans. Fenitrothion is an Acetylcholinesterase inhibitor and Carcinogenic. Fenitrothion with complex structure has high persistence in ecosystem and biosphere. The target aim of this study is to eliminate FEN residues from contaminated sites specifically in Paddy soils with Fungi. Isolate the Fenitrothion degraded fungi by the Screening process and check the potential degradation levels in both solid \& liquid media's and here the potential isolate uses phosphate as an energy source, examine the fungi under the microscope. The Pure fungi are subject for Molecular characterization with 26S rDNA gene sequencing and phylogenetic analysis and identified as Aspergillus parasiticus.
\end{abstract}

Keywords: Fenitrothion, Acetyl cholinesterase, Neurotoxicant \& Carcinogenic, 26S rDNA, Phylogenetic analysis.

*Correspondence: sudhapakala84@gmail.com; +91-9515421765.

(Received: 23 October 2018; accepted: 03 December 2018)

Citation: T. Sudha Rani and P. Suvarnalatha Devi, Isolation and Characterization of Fenitrothion (Organophosphate Insecticide) Degrading Fungi from Paddy Fields, J Pure Appl Microbiol., 2018; 12(4):2321-2326. http://dx.doi.org/10.22207/JPAM.12.4.74

C The Author(s) 2018. Open Access. This article is distributed under the terms of the Creative Commons Attribution 4.0 International License which permits unrestricted use, sharing, distribution, and reproduction in any medium, provided you give appropriate credit to the original author(s) and the source, provide a link to the Creative Commons license, and indicate if changes were made. 


\section{INTRODUCTION}

Insecticides are substances or preparation used for killing insect pests, include ovicides and larvicides. Insecticides are commonly used in agriculture, industry, medicine.

Insecticides are pesticides that are formulated to kill, harm one or more species of insect. Insecticides effects insects in various ways that it disrupts the nervous system, may damage their exoskeletons, repel them. Insecticides commonly used as sprays, dusts, gels, baits.

A pesticide may be a chemical substance like Inorganic, Organic Pesticides, a Biological agent like Virus, Bacteria and Antimicrobial agents. Including Insecticides, Pesticides are grouped as Fungicides, Bactericides, Ovicides, Larvicides, Adulticides, Herbicides, Nematicides, Virucides, Molluscicides etc. Based on mode of action Pesticides are grouped as Fumigants, Stomach Poisons, Systemic Poisons, Contact Poisons etc.

Basing on the chemical structure Pesticides are Organochlorines, Organophosphate, Carbamates. The pesticide selected for present work is Organophosphate Pesticide.

The commonly used Organophosphates are Parathion, Malathion, Fenitrothion, Methyl parathion, Diazinon, Dichlorvos, Phosmet etc. In the present work, Fenitrothion is selected for Degradation. Trade names include Accothion, Metathion, Malathion, Pestroy, Sumothion, Verthion. The common name is Methylnitrophos and considered as a Cholinesterase inhibitor. Fenitrothion acts on Pests like penetrating, Chewing, commonly acts on Cotton, Rice, cereals, Vegetables. It's commonly used as Mosquito, fly, cockroach as contact sprays for farms and Public Programs.

Fenitrothion is flowable, It is available in different emulsifiable concentrations like $95 \%, 50 \%$, the molecular formula is $\mathrm{C}_{9} \mathrm{H}_{12} \mathrm{NO}_{5} \mathrm{PS}$, the chemical class is organophosphate/contact insecticide, the specific gravity is $1.3227 ; 1.32 ; 1.34 ; 1.3084$ at 20degreed C.

\section{Toxicological Effects}

Fenitrothion is an acetylcholinesterase inhibitor and neurotoxicant, fenitrothion forms a strong covalent bond to the enzyme acetylcholinesterase, which catalyses the acetylcholine. Fenitrothion is toxic, at chronic levels suppress the growth of algae, Fenitrothion is toxic to crayfish, nontarget organisms of the ecosystem, it is highly toxic to honeybees, rats. For humans it is Carcinogenic, Fenitrothion residues persist a long time in the environment, so the target of the study is to eliminate the Fenitrothion residues.

\section{MATERIALS AND METHODS}

\section{Enrichment of Fenitrothion degrading fungi}

From the Paddy fields of Pakala, Chittoor District, Andhra Pradesh with a continuous history of farming for more than 35 years the soil samples at the depth 0-16 cm was collected, transported to the laboratory in plastic bags, and stored at $4^{\circ} \mathrm{C}$ for further analysis.

By using an inoculum of Fenitrothion treated soil Fenitrothion degrading fungi were isolated by the enrichment culture technique, 10 $\mathrm{g}$ of soil sample was diluted and inoculated in 250 $\mathrm{ml}$ Erlenmeyer flasks with $100 \mathrm{ml}$ potato dextrose broth at the temperature of $28^{\circ} \mathrm{C}$ for $24 \mathrm{~h}$.

$1 \mathrm{ml}$ of microbial suspension was poured into potato dextrose flasks to isolate fenitrothion resistant fungi, spread plate method was selected for isolation of Fungi pure culture. From enrichment culture One loop full of fenitrothion resistant fungi were spread on potato dextrose plates which are amended with fenitrothion, incubate the plates at 24-48h for the growth of the fungi colonies at $28^{\circ} \mathrm{C}$. Basing on the morphological characters different colonies were isolated and sub-cultured on potato dextrose plates and maintained at $37^{\circ} \mathrm{C}$ for fungi characterization.

Flask without inoculums was also prepared for the biotic disappearance of the Fenitrothion and kept for incubation at $28^{\circ} \mathrm{C}$ for $24 \mathrm{~h}$.

\section{Screening of pesticide resistance fungi}

To observe the fenitrothion resistance fungi, the selected colonies of fungi were poured on potato dextrose plates with higher concentrations of fenitrothion like 10,25,50,75,100 $\mathrm{ppm}$. The fungi which show the growth at this ppm concentration were screened for preceding work.

\section{Preparation of Pure culture}

Spread plate method was chosen for isolation of Fungi pure culture. The enrichment culture of fenitrothion resistant fungi one loop full were spread on potato dextrose plates which are amended with fenitrothion, and incubate at 24- 
$48 \mathrm{~h}$ at $28^{\circ} \mathrm{C}$. The different colonies were isolated and sub-cultured on potato dextrose plates at $37^{\circ} \mathrm{C}$ for fungi characterization.

Screening of Potential fenitrothion degrading fungi strains

To screen the potential degrading fungi of fenitrothion the purely isolated fungi were spiked on Czepak-dox agar amended with fenitrothion of higher concentrations like 200,300, 400 ppm. The degradation of the fenitrothion was also checked in Czepak-dox liquid.

\section{Morphological characteristics of fungi}

The morphological characters of the fungi strain degrade the fenitrothion were observed with already identified other strains, namely the colour of spores, mycelial colour, conidiosphore structure were observed microscopically, radial growth of the test organisms was observed. Molecular characterization has proceeded for identification of the isolated fungi.

\section{Preperation of genomic DNA}

Genomic DNA was isolated from $24 \mathrm{~h}$ old culture. The $100 \mu \mathrm{g}$ of mycelium was measured into a 1.5- microfuge tube ground the mycelium in a mortar and pestle treated with liquid $\mathrm{N}_{2}$ 5-6 times. The frozen powder was transferred to Eppendorf tube and 660-750 $\mu$ l of was added and $10 \mu \mathrm{l}$ of $\beta$-mercapor, vortex the mixture for few seconds and keep it for incubation at $65^{\circ} \mathrm{c}$ for $1 \mathrm{~h}$ by using water bath, later keep it for centrifugation at 3500 rpm for 5 minutes, collect the top aqueous layer in to a fresh Eppendorf tube and added 700 $\mu \mathrm{l}$ of chloroform, isopropanol (24:1) and adjust the volume to meet a 1:1ratio of aqueous phase, centrifuge at $12000 \mathrm{rpm}$ for 10 minutes and followed by $70 \% 0.5 \mathrm{ml}$ ethanol and centrifuge for about 5 minutes, collect the pellet and treated with $100 \mu$ l of TE buffer (PH-8). After further purification DNA was quantified by spectrophotometrically keep it for gel electrophoresis.

\section{Amplification of 26s r DNA}

Polymerase chain reaction (PCR) was performed for the amplification of $26 \mathrm{~s}$ region of the isolated by using the universal primers, the reaction was performed a final volume $50 \mu \mathrm{l}$, template DNA 2.0 $\mu$ l, amplification was performed at different temperatures for 32 cycles. The amplification products were checked by resolving the PCR products in $1.8 \%$ agarose gel. The agarose solution was cooled at $40^{\circ} \mathrm{C}$ and $5 \mu$ of ethedium bromide solution was added. PCR products 5 $\mu \mathrm{l}$ were taken and mixed with $5 \mu$ of $6 \times$ gel loading buffer. Electrophoresis was performed for approximately $2.5 \mathrm{~h}$ at 50-100 mA. The PCR product was visualized on a gel doc (PCR-ABI 7200).

\section{Concentration of PCR Amplification mixture}

$\begin{array}{ll}\text { Template DNA (50ng) } & 2.0 \mu \mathrm{L} \\ 10 \mathrm{XmL} & 5.0 \mu \mathrm{L} \\ \begin{array}{l}\text { Forword \& Reverse Primer } \\ (2 \mathrm{mM} / \mathrm{mL})\end{array} & 8.0 \mu \mathrm{L}(4+4) \\ \text { Taq DNA Polymerase } & 0.5 \mu \mathrm{L} \\ (5 \mathrm{u} / \mu \mathrm{L}) & \\ 2 \mathrm{mM} \text { dNTP Mix } & 5.0 \mu \mathrm{L} \\ \text { Sterile distilled water } & 29.5 \mu \mathrm{L} \\ \text { Total volume } & 50.0 \mu \mathrm{L}\end{array}$

\section{Amplification in PCR}

PCR amplification was processed in a primus advanced gradient Thermocycler and the conditions are

\begin{tabular}{lcc} 
PCR steps & Temperature & Minutes \\
\hline $\begin{array}{l}\text { Initial } \\
\text { denaturation }\end{array}$ & $94^{\circ} \mathrm{C}$ & 5 minutes \\
$\begin{array}{l}\text { Denaturation } \\
35 \text { cycles }\end{array}$ & $94^{\circ} \mathrm{C}$ & 30 seconds \\
Annealing & $56^{\circ} \mathrm{C}$ & 30 seconds \\
Elongation & $72^{\circ} \mathrm{C}$ & 30 seconds \\
Final extension & $72^{\circ} \mathrm{C}$ & 10 minutes
\end{tabular}

\section{Molecular Characterization by 26 s r DNA}

Molecular identification has been carried out using specific 26 s r DNA gene sequencing Kurtzman et al., (1997).

\section{Analysis of sequence}

The analysis of the $26 \mathrm{~s} r$ DNA gene sequence was checked with $26 \mathrm{~s} r$ DNA gene sequences of other organisms that had already been submitted to Gene Bank database using the BLASTN of bioinformatics software chromas. (http:/www.ncbi.nlm.nih.gov).

\section{RESULTS}

The complete work focused on the Isolation and characterization of the Fungi stains which shows resistance to Insecticide (Fenitrothion), to identify potential fungi for the fenitrothion bioaugmentation. Diverse colonies were observed, among them one fungus were selected because of their potential growth on fenitrothion amended Czapadex media. 


\section{Isolation of Fenitrothion resistant fungi}

With enrichment culture technique 9 fungi were isolated, when these cultures were subject for potential degradation of fenitrothion with higher ppm concentrations like 300, 400 ppm only one fungus shows good degradation when compared to others. So one fungus was isolated.

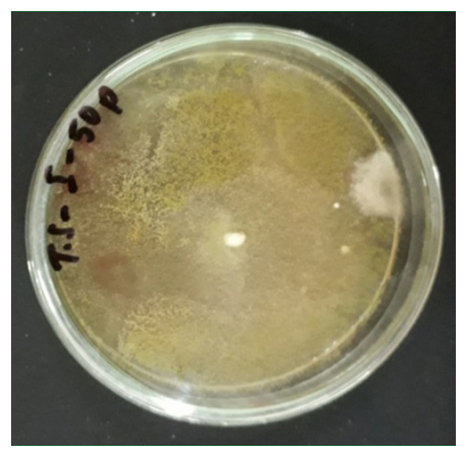

Fig. 1. Microscopic Observation of pesticide degrading Fungi

Table 1. Morphological characteristics

\begin{tabular}{ll}
\hline Characteristics & \multicolumn{1}{c}{ Fungi } \\
\hline Surface colours & $\begin{array}{l}\text { green to dark green } \\
\text { entire }\end{array}$ \\
Margins & greenish yellow \\
Reverse side & Rapid \\
\hline
\end{tabular}

Microscopic observation of pesticide degrading fungi

The fungi isolates were observed microscopically, Morphological characters were discussed in Table 1 \& 2.

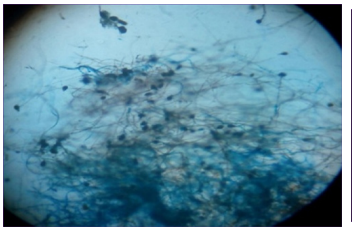

Fig. 2. 10x observation

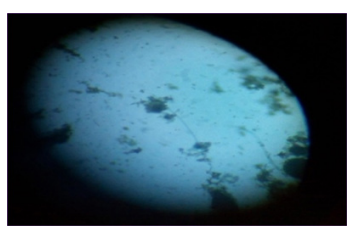

Fig. 3. 40x observation

Table 2. Microscopic characters

\begin{tabular}{ll}
\hline Characteristics & \multicolumn{1}{c}{ Fungi } \\
\hline Hyphae & Branched septae \\
Conidiophores & present \\
Vesicle & dome shaped \\
Conidia & present \\
Phialides & uniseriate \\
Fruting body & cleistothecia \\
\hline
\end{tabular}

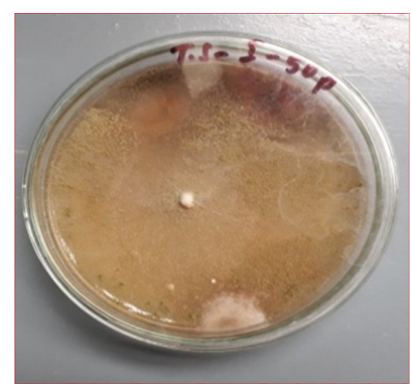

Fig 4. $50 \mathrm{ppm}$

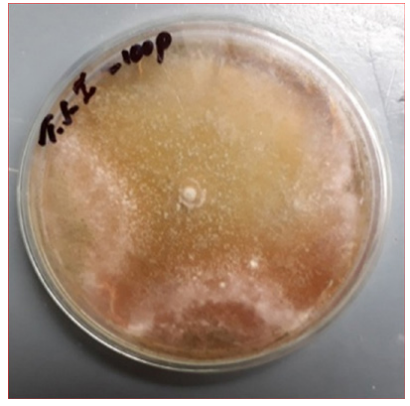

Fig. 5. $100 \mathrm{ppm}$

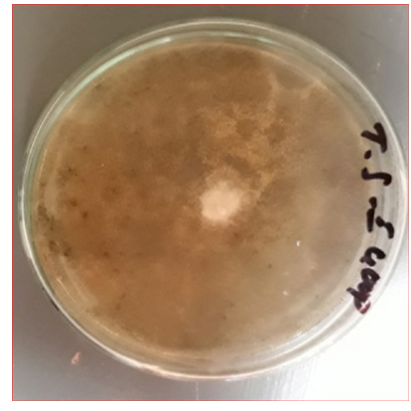

Fig. 6. $400 \mathrm{ppm}$

(Fenitrothion degradation at different ppm concentration's)

Isolation of Potential fenitrothion degrading fungi

The selected fungi degrade the fenitrothion at higher concentrations like 50, 100, 400 ppm.

Degradation of fenitrothion in liquid broth

The fenitrothion degradation is also checked in Czepak-dox liquid.

\section{Genomic DNA extraction}

When agarose gel was illuminated to UV light1 band of genomic DNA was identified, when compared with $1 \mathrm{~Kb}$ DNA marker. Lane one indicates the DNA marker and lane 2 indicates the fungi genomic DNA. The Isolated gene has intimated in Fig. 7. 
1

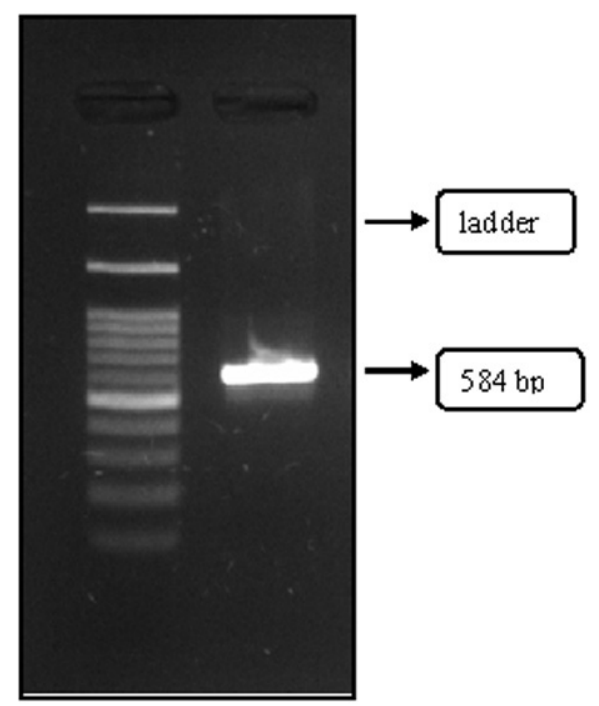

Fig. 7. PCR amplification- the $26 \mathrm{~s} r$ DNA gene yielded a 584 bp PCR Product

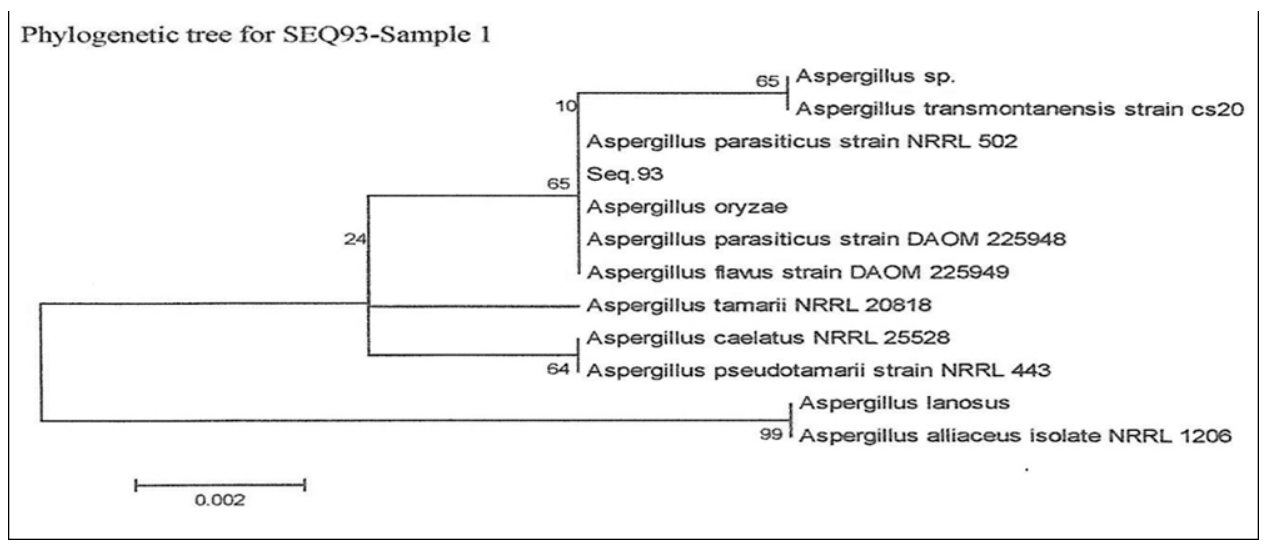

Phylogenetic analysis Report

Nine fungi colonies were isolated, basing on their active growth on fenitrothion amended media one fungi was selected for present work. Basing on their microscopic, Morphological appearance, Molecular characterization the Fungi was identified as Aspergillus parasiticus. When compare to other eight isolates the Aspergillus parasiticus degrade the Fenitrothion up to $400 \mathrm{ppm}$ concentration, and also the degradation of fenitothion were also determined

65. Aspergillus sp.

Aspergillus transmontanensis strain cs20

\section{ACKNOWLEDGEMENTS} facilities.

\section{DNA sequencing analysis of $26 s$ r DNA gene}

After $26 \mathrm{~s} r$ DNA gene sequencing the highest degree of similarity found was $100 \%$ with already submitted organisms, and the value obtained the $26 \mathrm{~s} r$ DNA gene of Aspergillus parasiticus. Based on these observations the isolate was identified as Aspergillus parasiticus.

\section{DISCUSSION}

Organophosphorus Insecticides are useful because of their low cost, more effective against Insect Pests, but remains a major environmental contaminant, make clinical problems in humans and other organisms, make microbial imbalance of soil, The excessive pollution of the ecosystem has been formed by organophosphorus pesticides, which is used for fields in Agriculture. The present study, the fenitrothion degrading fungi were isolated by enrichment culture technique, enrichment cultures from the soil which utilize organophosphate as the major source for their growth. Sheela and Pai used enrichment culture technique for degradation of organophosphates.

by Chromatorgaphic techniques like FTIR, GCMS, HPLC, which is discussed on my further articles, Organophosphourus hydrolase (OPH) has the ability of hydrolyzing organophosphorus pesticide.

We would like to thank the DST-CURIE, Co-ordinator and staff (Sri Padmavati Mahila Visvavidyalayam, Tirupati) for providing their lab 


\section{REFERENCES}

1. Arata Katayama and Fumio Mastsumura. Degradation of Organochlorine pesticides, particularly endosulfan, by Trichoderma hazianum. Environmental Toxicology and chemistry. 2009;12(6):1059-1065.

2. Worthing, C.R.(ed) The Pesticide Manual; A World Compendium, seventh edition, published by The British Crop Protection Council, 1983.

3. Hassall,K.A. The Biochemistry and users of pesticides: Structure, Metabolism, Mode of Action and uses in Crop Protectio, 2 nd edition. VCH Publisher, 1990.

4. Spadotto, C.A; Gomes, M.A.F; Lunchi, L.C; Andrea, M.M; Monitoramento do Risco Ambiental de Agrotoxocos; Principiose Recomendacoes, Embrapa Meio Ambiente; jaguariuna, Brasil, 2004

5. P. J. john, Alteration of certain blood parameters of freshwater teleost Mystrus vittatus after chronic exposure to Metasystox and Sevin, Fish Physiol. Biochem, 2007, 33:15-20.

6. O.E. Fagade, and E.M. Adetutu, Lead solubilisation and accumulation by two stains of Pseudomonas species obtained from a battery manufacturing factory effluent. Nigeria J Microbial, 1999; 13: 39-46

7. P. Vandevivere, and W. Verstraeete, Environmental applications, in basic Biotechnology. 2 nd edition, Cambridge University Press, Cabridge, 2002, 531-557.

8. H.Zolgharnein, M.L.M.M Azmmi, M.Z. Saad, A.R.Mutalib, and C.A.R. Mohamed, Detection of plasmids in heavy metals resistance bacteria isolated from the Persian Gulf and enclosed industrial areas. Irani.j. Biotechnol, 2002; 5:232239.

9. G.J. Tortora, B.R. Funke, and C.L Case, Microbiology: an Introduction (Benjamin/ comings Publishing Company. California.USA, 1998), 169-176.

10. H.J. Benson, Microbiological applications- A laboratory manual in general microbiology, $5^{\text {th }}$ edition, Ed. WCB. 1990.

11. T. Vinntila, and L.D. Dinu, Technologia produselor de biosinteza-Manual de laborator, Ed.Orizonturi Universitare, Timisoara, 2004.

12. C.H. Collins, P.M.Lyne, and J.M. Grange, Microbiological methods. ButterworthHeinenmann Ltd.Oxford. England. 1995,493.

13. A.W.F. Harrigian, and M.E.Mc Cane, Laboratory methods in food and dairy microbiology. Academic, London, 1976, 452.

14. H.W. Seely, and P.J Van Y Denmark, Microbes in action-a laboratory manual of microbiology. Freeman, San Francisco, 1972,361.

15. J.F. Mac Fadin, Biochemical test; identification of medical bacterial. Williams and Wilkins.London, 2009.

16. F.E. Loffler, Q. Sun, J.R.Li, and J.M. Tiedje, 6 S Rrna gene-based detection of tetrachloroethenedchlorinating Deulfuromonas and Dehalococcoides species, App.Environ. Nicrobial, 2000; 66:1369-1374.

17. A. Rosenberg, and M.Alexander, Microbial cleavage of various organophosphorus insecticides. Appl.Environ.Microbial, 1979; 37 (5):886-91. 